\section{Article}

CHITOLINA, G.M.'

MENDES, K.F. ${ }^{2 *} \mathbb{D}$

ALMEIDA, C.S. ${ }^{1}$

ALONSO, F.G.'

JUNQUEIRA, L.V.'

TORNISIELO, V.L.' (D)

\title{
INFLUENCE OF SOIL DEPTH ON SORPTION AND DESORPTION Processes of Hexazinone
}

\section{Influência da Profundidade do Solo nos Processos de Sorção e Dessorção do Hexazinone}

\begin{abstract}
Herbicides with a high leaching capacity, such as hexazinone, tend to reach deeper soils more easily, where retention of the product affects its availability in the soil solution. Therefore, it is important to understand the behavior of hexazinone at a variety of soil depths. The objective of this research was to evaluate the sorption and desorption of hexazinone throughout the soil profile. The sorption and desorption processes of ${ }^{14} \mathrm{C}$-hexazinone [triazine- $6-{ }^{14} \mathrm{C}$ ] at three soil depths $(0-10,10-20$, and $20-30 \mathrm{~cm}$ ) were evaluated by the equilibrium batch method, and the radioactivity of the herbicide was quantified by liquid scintillation spectrometry. Five different concentrations of hexazinone $\left(0.12,0.19,0.25,0.31\right.$, and $\left.0.38 \mu \mathrm{g} \mathrm{mL}^{-1}\right)$ in a methanol solvent were used. The concentrations of the herbicide in equilibrium and sorbed in the soil were adjusted by using isotherms according to the Linear, Freundlich, and Langmuir models. Hexazinone sorption at soil depths of 0-10, 10-20, and 20-30 cm showed decreasing Freundlich coefficients $\left(\mathrm{K}_{\mathrm{f}}\right)$ with values of 0.18 , 0.11 , and $0.08 \mathrm{~g}^{(1-1 / \mathrm{n})} \mathrm{L}^{1 / \mathrm{n}} \mathrm{kg}^{-1}(50.49,47.58$, and $46.37 \%$ sorbed $)$, and in the desorption the $\mathrm{K}_{\mathrm{f}}$ were 7.96, 7.93, and $9.82 \mathrm{~g}^{(1-1 / \mathrm{n})} \mathrm{L}^{1 / \mathrm{n}} \mathrm{kg}^{-1}(26.17,26.58$, and $28.68 \%$ desorbed), respectively. The small difference in organic carbon content between soil depths was sufficient to affect hexazinone retention, interfering with the bioavailability of this product in the soil solution for weed control.
\end{abstract}

Keywords: retention isotherms, mobile herbicide bioavailability.

RESUMO - Herbicidas com grande capacidade de lixiviação, como o hexazinone, tendem a atingir com mais facilidade as camadas mais profundas do solo, afetando a disponibilidade do produto na solução do solo pela retenção. Portanto, é importante compreender o comportamento do hexazinone em uma variedade de profundidades do solo. O objetivo desta pesquisa foi avaliar os processos de sorção $e$ dessorção do hexazinone ao longo do perfil do solo. Os processos de sorção e dessorção do ${ }^{14} \mathrm{C}$-hexazinone [triazine- $6-{ }^{14} \mathrm{C}$ ] em três profundidades do solo $(0-10$, 10-20 e 20-30 cm) foram avaliados pelo método de equilíbrio de batelada em lotes, analisando-se a radioatividade do herbicida foi quantificada por espectrometria de cintilação líquida. Foram utilizadas cinco diferentes concentrações do hexazinone $\left(0,12,0,19,0,25 ; 0,31\right.$ e 0,38 $\left.\mu \mathrm{g} \mathrm{mL}^{-1}\right)$ em solvente metanol. As concentrações do herbicida em equilíbrio e sorvidas no solo foram ajustadas usando isotermas de acordo com os modelos Linear, Freundlich e Langmuir. A sorção do hexazinone nas profundidades do solo de 0-0, 10-20 e 20-30 cm apresentou coeficientes de Freundlich $\left(K_{f}\right)$ decrescentes com valores de 0,18, 0,11 e 0,08 $\mathrm{g}^{(1-1 / n)} \mathrm{L}^{1 / n} \mathrm{~kg}^{-1}$ (50,49, 47,58 e 46,37\% sorvido); e na dessorção os $K_{f}$ foram de 7,96, 7,93 e 9,82 mmol (1-1/n) $\mathrm{L}^{1 / n} \mathrm{~kg}^{-1}$ (26,17, 26,58 e 28,68\% dessorvido),

${ }^{1}$ Universidade de São Paulo, Piracicaba-SP, Brasil; ${ }^{2}$ Universidade Federal de Viçosa, Viçosa-MG, Brasil. 
respectivamente. A pequena diferença no teor de carbono orgânico entre as profundidades do solo foi suficiente para afetar a retenção do hexazinone, interferindo na biodisponibilidade deste produto na solução do solo para o controle de plantas daninhas.

Palavras-chave: isotermas de retenção, herbicida móvel, biodisponibilidade.

\section{INTRODUCTION}

Herbicides applied in agriculture for weed control always reach the soil, regardless of the mode of application. As soon as they come into contact with soil particles, herbicides are subjected to several biotic and abiotic factors, which influence their final destination and their behavior in the environment (Mancuso et al., 2011).

One of the destinations of herbicides is binding to soil particles. This phenomenon, called sorption, is more related to soil organic carbon $(\mathrm{OC})$ than to any other soil property, as is the case for hexazinone (Koskinen et al., 1996). Therefore, understanding the processes of herbicide sorption and desorption in the soil is extremely important, since these processes determine herbicide bioavailability, mobility, and degradation, as well as the possibility of contamination of other environmental compartments. The determinant factors in the sorption and desorption of herbicides in the soil, in general, are the physical, chemical, and biological properties of the soil, the environmental conditions, and the physicochemical properties of the herbicide (Bonfleur et al., 2015; Cha et al., 2016).

Leaching of herbicides in soils with a smaller amount of OC may leave the product exposed to the changes brought about by soil depth, such as changes in $\mathrm{pH}$, microbial activity, and the quantity of organic matter in the soil, especially in the sorption and desorption of products in deeper soils, which depends on attributes such as clay and organic matter content (Taylor et al., 2004). From an environmental point of view, improving the amount of OC below the soil surface is a great option to control the target of herbicides, because in most soils the OC content decreases with increasing soil depth (Gaudinski et al., 2000; Wynn et al., 2005). Corroborating this, the weed seed bank is concentrated in the subsurface layer of the soil and is essential to the study of the product's ability to control weeds (Amim et al., 2016).

Hexazinone [3-cyclohexyl-6-(dimethylamino)-1-(dimethylamino)-1-methyl-1, 3,5-triazine-2$4(1 \mathrm{H}, 3 \mathrm{H})$ diona] belongs to the triazinone group. This herbicide has a residual effect on the soil and is used to control a wide variety of weeds, whether annual, biennial, or perennial. Hexazinone is registered in Brazil for sugar cane crops (Rodrigues and Almeida, 2018) and has a low coefficient of sorption relative to $\mathrm{OC}\left(\mathrm{K}_{\mathrm{oc}}=54 \mathrm{~L} \mathrm{~kg}^{-1}\right)$, high persistence in the soil, represented by a high half-life (DT50 = 105 days), and high leaching potential throughout the soil profile, possessing a Groundwater Ubiquity Score (GUS) Index of 4.43 (PPDB, 2019). A study conducted by Koskinen et al. (1996) showed the relationship of soil properties in the sorption and desorption of hexazinone, where the increase in soil depth from $0-5$ to $15-20 \mathrm{~cm}$ decreased the OC content from $7.63 \%$ to $4.27 \%$. Concurrently, the same authors reported that the reduction of OC content directly influenced the values of the sorption coefficient $\left(\mathrm{K}_{\mathrm{d}}\right)$, which ranged from 1.10 to $0.0632 \mathrm{~L} \mathrm{~kg}^{-1}$ and from $\mathrm{K}_{\text {oc }}$, from 25.7 to $8.28 \mathrm{~L} \mathrm{~kg}^{-1}$, as the soil depth increased, demonstrating that the variation in $\mathrm{OC}$ content with depth affected the retention of this product.

To adjust for the process of sorption and desorption of herbicides in the soil, researchers frequently use isotherms that adjust for the concentration of the product in equilibrium in the soil solution and sorbed onto it, in particular, the Linear, Freundlich, and Langmuir isotherms (Green and Karickhoff, 1990).

In view of the above, the objective of this research was to evaluate the sorption and desorption processes of hexazinone throughout the soil profile. The results of this study will help to elucidate the behavior of this mobile herbicide at different soil depths, as comprehension of its bioavailability is necessary for weed control. 


\section{MATERIAL AND METHODS}

\section{Soil}

The soil used was collected in Piracicaba, SP, Brazil (S 2242’52", W 47³7’10"), classified as Ultisol - Typic Hapludalf, in layers 0-10, 10-20, and 20-30 cm deep, by means of a probe-type auger (model SCTS-40). After drying at room temperature, the samples were sifted through $2 \mathrm{~mm}$ mesh and stored at room temperature until analysis. The physicochemical properties of soil samples taken at each depth are shown in Table 1.

Table 1 - Physicochemical properties of the different soil depths used in this study

\begin{tabular}{|c|c|c|c|c|c|c|c|c|}
\hline \multirow{2}{*}{$\begin{array}{l}\text { Soil depth } \\
\text { (cm) }\end{array}$} & $\mathrm{K}$ & \multicolumn{2}{|c|}{$\mathrm{Ca}^{2+}$} & $\mathrm{Mg}^{2+}$ & \multirow{2}{*}{\multicolumn{2}{|c|}{$\mathrm{H}+\mathrm{Al}$}} & BS & $\mathrm{CEC}$ \\
\hline & \multicolumn{7}{|c|}{$\left(\mathrm{mmol}_{\mathrm{c}} \mathrm{kg}^{-1}\right)$} & \\
\hline $0-10$ & 2.7 & \multicolumn{2}{|c|}{19} & 8 & 11 & & 29.7 & 40.7 \\
\hline $10-20$ & 1.7 & \multicolumn{2}{|c|}{18} & 8 & 11 & & 27.7 & 38.7 \\
\hline \multirow[t]{3}{*}{$20-30$} & 2.0 & \multicolumn{2}{|c|}{19} & 7 & 11 & & 28.0 & 39.0 \\
\hline & \multirow{2}{*}{$\begin{array}{c}\mathrm{pH} \\
\left(\mathrm{CaCl}_{2}\right)\end{array}$} & \multirow{2}{*}{$\begin{array}{c}\mathrm{P} \\
\left(\mathrm{mg} \mathrm{dm}^{-3}\right)\end{array}$} & \multirow{2}{*}{$\begin{array}{l}\mathrm{V} \\
(\%)\end{array}$} & \multirow{2}{*}{$\begin{array}{l}\mathrm{OC} \\
(\%)\end{array}$} & Clay & Silt & Sand & \multirow{2}{*}{ Textural class } \\
\hline & & & & & \multicolumn{3}{|c|}{$\left(\mathrm{g} \mathrm{kg}^{-1}\right)$} & \\
\hline $0-10$ & 4.8 & 22 & 73 & 0.69 & 176 & 39 & 785 & \multirow{3}{*}{ Sandy loam } \\
\hline $10-20$ & 5.0 & 10 & 72 & 0.46 & 203 & 22 & 775 & \\
\hline $20-30$ & 5.2 & 7 & 72 & 0.40 & 177 & 60 & 764 & \\
\hline
\end{tabular}

$\mathrm{K}=$ potassium; $\mathrm{Ca}=$ calcium; $\mathrm{MG}=$ Magnesium; $\mathrm{H}+\mathrm{Al}$ : acidity potential; $\mathrm{BS}=$ base saturation; $\mathrm{CEC}=$ cation exchange capacity; $\mathrm{pH}=$ hydrogen potential; $\mathrm{P}=$ phosphorus; $\mathrm{V}=$ saturation level per base; $\mathrm{OC}=$ organic carbon. Source: Department of Soil Science-ESALQ/USP, Piracicaba, SP, Brazil.

\section{Hexazinone herbicide}

The ${ }^{14} \mathrm{C}$-Hexazinone [triazine- $6-{ }^{14} \mathrm{C}$ ] (radiolabeled), supplied by the company Izotop (Budapest, Hungary), had a radiochemical purity of $99.7 \%$ and a specific activity of $3.14 \mathrm{MBq} \mathrm{mg}^{-1}$. An analytical standard (non-radiolabeled) with a chemical purity of $99.9 \%$ was acquired from Sigma Aldrich (Saint Louis, MO, USA). A solution with the analytical pattern (radiolabeled and nonradiolabeled) in methanol was prepared carefully using different concentrations of the herbicide $\left(0.12,0.19,0.25,0.31\right.$, and $\left.0.38 \mu \mathrm{g} \mathrm{mL} \mathrm{m}^{-1}\right)$. The initial radioactivity $(\sim 1528 \mathrm{~Bq}$ per vial) of the herbicide was verified by placing $1 \mathrm{~mL}$ of a sample at each concentration prepared in liquid scintillation vials containing $10 \mathrm{~mL}$ of the scintillation solution. The radioactivity of samples in each vial were analyzed in a Liquid Scintillation Counter (LSC) (Tri-Carb 2910 TR LSA, LSA PerkinElmer, Waltham, MA, USA) for 5 minutes.

\section{Sorption and desorption studies}

Sorption studies were performed by the batch balancing method, according to the guidelines of the "Organisation for Economic Co-operation and Development - 106" (OECD, 2000). Teflon tubes with 50-mL screw caps were labelled and weighed. Each tube received $5 \mathrm{~g}$ of soil and $5 \mathrm{~mL}$ of aqueous solution of $\mathrm{CaCl}_{2} 0.01 \mathrm{~mol} \mathrm{~L}^{-1}$ containing the herbicide, in a proportion of 1:1 ( $\left.\mathrm{w} \mathrm{v}^{-1}\right)$. The tubes were prepared in duplicate and subjected to agitation in a horizontal pendular table (Tecnal Equipamentos Scientific, model TE-240, Piracicaba, SP, Brazil) at $200 \mathrm{rpm}$ in a dark environment at $20^{\circ} \mathrm{C}$ for 24 hours to equilibrate (Koskinen et al., 1996).

After the equilibration period, the tubes were centrifuged at $3000 \mathrm{rpm}$ for 15 minutes (Hitachi CF16RXII, Hitachi Koki Co., Ltd., Indaiatuba, SP, Brazil) to separate the solution from the soil. After centrifugation, 1-mL aliquots of the supernatant from each tube were collected in duplicate and placed in scintillation flasks containing $10 \mathrm{~mL}$ of scintillation solution, and each sample was analyzed by LSC for 5 minutes. The concentration of the herbicide sorbed in the soil was calculated as the difference between the initial concentration of the product and the concentration after the equilibration period.

The desorption study was performed shortly after the sorption study. In the same Teflon tubes, $5 \mathrm{~mL}$ of a new aqueous solution of $\mathrm{CaCl}_{2} 0.01 \mathrm{~mol} \mathrm{~L}^{-1}$ (non-radioactive) was added, and the 
old solution was discarded as radioactive waste. The tubes were again equilibrated for 24 hours with agitation on a shaking platform under the same conditions as in the sorption study. The tubes were centrifuged again, and $1 \mathrm{~mL}$ aliquots in duplicate supernatants were transferred to scintillation flasks containing $10 \mathrm{~mL}$ of scintillation solution for the analysis of sample radioactivity with the herbicide, performed by LSC for 5 minutes per sample. The amount of herbicide desorbed was calculated as the difference in the concentration of the solution before and after desorption.

\section{Sorption and desorption model}

The linear sorption coefficients were calculated $\left(\mathrm{K}_{\mathrm{d}}, \mathrm{L} \mathrm{kg}^{-1}\right)$ according to the following equation:

$$
\mathrm{K}_{\mathrm{d}}=\frac{\mathrm{C}_{\mathrm{s}}}{\mathrm{C}_{\mathrm{f}}}
$$

in which $\mathrm{C}_{\mathrm{s}}$ is the concentration of herbicide sorbed in the soil $\left(\mathrm{mg} \mathrm{kg}^{-1}\right)$, and $\mathrm{C}_{\mathrm{e}}$ is the concentration of the herbicide in equilibrium in the soil solution $\left(\mathrm{mg} \mathrm{L}^{-1}\right)$.

The coefficients of sorption $\mathrm{K}_{\mathrm{f}}$ and $1 / \mathrm{n}$ were determined by the Freundlich isotherm model:

$$
\mathrm{C}_{\mathrm{s}}=\mathrm{K}_{\mathrm{f}} \mathrm{C}_{\mathrm{e}}{ }^{1 / \mathrm{n}}
$$

in which $\mathrm{C}_{\mathrm{s}}$ is the amount of herbicide sorbed in the soil $\left(\mathrm{mg} \mathrm{kg}^{-1}\right)$; $\mathrm{K}_{\mathrm{f}}$ is the balance constant of Freundlich $\left(\mathrm{mg}^{(1-1 / \mathrm{n})} \mathrm{L}^{1 / \mathrm{n}} \mathrm{kg}^{-1}\right) ; \mathrm{C}_{\mathrm{e}}$ is the concentration of the herbicide in equilibrium in the soil solution $\left(\mathrm{mg} \mathrm{L}^{-1}\right)$; and $1 / \mathrm{n}$ is the degree of linearity of the isotherm.

The expression of the Langmuir isotherm was represented by the following equation:

$$
\mathrm{C}_{\mathrm{s}}=\frac{q_{\max } \mathrm{K}_{1} \mathrm{C}_{\mathrm{e}}}{1+q_{\max } \mathrm{C}_{\mathrm{e}}}
$$

in which $\mathrm{C}_{\mathrm{s}}$ is the concentration of herbicide sorbed in the soil $\left(\mathrm{mg} \mathrm{kg}^{-1}\right) ; q_{\max }$ is the maximum herbicide concentration when the site surface is saturated $\left(\mathrm{mg} \mathrm{g}^{-1}\right)$; $\mathrm{K}_{1}$ is the Langmuir equilibrium constant $\left(\mathrm{L} \mathrm{mg}^{-1}\right)$; and $\mathrm{C}_{\mathrm{e}}$ is the concentration of the herbicide in equilibrium in the soil solution $\left(\mathrm{mg} \mathrm{L}^{-1}\right)$.

The sorption coefficients were normalized to the soil OC content $\left(\mathrm{K}_{\mathrm{oc}}, \mathrm{L} \mathrm{kg}^{-1}\right)$, and the coefficients $\mathrm{K}_{\mathrm{foc}}$ and $\mathrm{K}_{\mathrm{loc}}$ were similarly determined as follows:

$$
\mathrm{K}_{\mathrm{oc}}=\frac{\mathrm{K}_{\mathrm{d}}}{\% \mathrm{OC}} \times 100
$$

The values of $\mathrm{K}_{\mathrm{f}}$ and $1 / \mathrm{n}, \mathrm{K}_{1}$ and $q_{\max }$, and $\mathrm{K}_{\mathrm{d}}$ of desorption were determined in a similar manner to the sorption coefficients, in which the remaining amount of herbicide sorbed in the soil returns to the equilibrium solution, being desorbed. The hysteresis coefficient $(\mathrm{H})$ was calculated by using the parameters that originated from the Freundlich isotherms for sorption $\left(1 / \mathrm{n}_{\text {sorption }}\right)$ and desorption $\left(1 / \mathrm{n}_{\text {desorption }}\right)$, with the following formula (Barriuso et al., 1994):

$$
\mathrm{H}=\frac{1 / \mathrm{n}_{\text {desorption }}}{1 / \mathrm{n}_{\text {sorption }}}
$$

\section{Statistical analysis of data}

The data obtained in the sorption and desorption studies of hexazinone at different soil depths were expressed as means, followed by the standard deviation of each mean value obtained $(n=2)$. The hexazinone sorption and desorption isotherms of the three models were plotted using Sigma Plot ${ }^{\circledR}$ (version 10.0 for Windows, Systat Software Inc., Point Richmond, CA, USA). 


\section{RESULTS AND DISCUSSION}

\section{Hexazinone sorption and soil depth}

The values of the coefficient of determination $\left(\mathrm{R}^{2}\right)$ are close to 1 in all three models of hexazinone sorption isotherms, and this indicates that the estimated curves were able to explain the observed points (Table 2).

Table 2 - Parameters of the sorption isotherms of the Linear, Freundlich and Langmuir model for hexazinone applied at different soil depths

\begin{tabular}{|c|c|c|c|c|c|c|c|c|c|c|c|c|}
\hline \multirow{3}{*}{$\begin{array}{l}\text { Soil depth } \\
\quad(\mathrm{cm})\end{array}$} & \multicolumn{3}{|c|}{ Linear $^{(1)}$} & \multicolumn{4}{|c|}{ Freundlich } & \multicolumn{4}{|c|}{ Langmuir } & \multirow{3}{*}{$\begin{array}{c}\text { Sorption } \\
(\%)\end{array}$} \\
\hline & $K_{d}$ & $\mathrm{~K}_{\mathrm{oc}}$ & \multirow{2}{*}{$\mathrm{R}^{2}$} & $\mathrm{~K}_{\mathrm{f}}$ & $\mathrm{K}_{\mathrm{foc}}$ & \multirow{2}{*}{$1 / \mathrm{n}$} & \multirow{2}{*}{$\mathrm{R}^{2}$} & $\mathrm{~K}_{1}$ & $\mathrm{~K}_{\mathrm{loc}}$ & $q_{\max }$ & & \\
\hline & \multicolumn{2}{|c|}{$\left(\mathrm{L} \mathrm{kg}^{-1}\right)$} & & \multicolumn{2}{|c|}{$\left(\mathrm{g}^{(1-1 / \mathrm{n})} \mathrm{L}^{1 / \mathrm{n}} \mathrm{kg}^{-1}\right)$} & & & \multicolumn{2}{|c|}{$\left(\mathrm{L} \mathrm{kg}^{-1}\right)$} & $\left(\mathrm{g} \mathrm{kg}^{-1}\right)$ & $\mathrm{K}^{2}$ & \\
\hline $0-10$ & $0.20 \pm 0.01$ & 28.57 & 0.99 & $0.18 \pm 0.01$ & 25.71 & $0.81 \pm 0.02$ & 0.99 & $0.92 \pm 0.03$ & 131.420 & $0.28 \pm 0.02$ & 0.99 & 50.49 \\
\hline $10-20$ & $0.13 \pm 0.02$ & 28.26 & 0.99 & $0.11 \pm 0.02$ & 23.91 & $0.79 \pm 0.03$ & 0.99 & $0.81 \pm 0.05$ & 176.90 & $0.16 \pm 0.03$ & 0.99 & 47.58 \\
\hline $20-30$ & $0.08 \pm 0.01$ & 19.51 & 0.99 & $0.08 \pm 0.02$ & 19.51 & $0.83 \pm 0.04$ & 0.99 & $1.20 \pm 0.16$ & 292.90 & $0.15 \pm 0.02$ & 0.98 & 46.37 \\
\hline
\end{tabular}

(1) Mean value of each parameter, \pm standard deviation of the mean $(n=2)$.

The sorption coefficients of the Freundlich $\left(\mathrm{K}_{\mathrm{f}}\right)$, Linear $\left(\mathrm{K}_{\mathrm{d}}\right)$, and Langmuir $\left(\mathrm{K}_{1}\right)$ models decreased proportionally to the sorption of hexazinone according to the increase in soil depth and with the variation in the amount of $\mathrm{OC}$ in it, suggesting that the decrease of $\mathrm{OC}$ in the soil reflected a lower retention of hexazinone (Table 1). The three sorption coefficients used obtained values ranging from 0.18 to $0.08 \mathrm{mg}^{(1-1 / \mathrm{n})} \mathrm{L}^{1 / \mathrm{n}} \mathrm{kg}^{-1}$ for $\mathrm{K}_{\mathrm{f}} ; 0.20$ to $0.08 \mathrm{~L} \mathrm{~kg}^{-1}$ for $\mathrm{K}_{\mathrm{d}}$; and 0.92 to $1.20 \mathrm{~L} \mathrm{~kg}^{-1}$ for $\mathrm{K}_{1}$ at soil depths of 0-10, 10-20, and 20-30 cm (Table 2).

A study conducted by Koskinen et al. (1996), using six types of sandy soils with depths varying from 0-5 to $90-95 \mathrm{~cm}$ also demonstrated the relationship between OC and the sorption of hexazinone, obtaining low values of $\mathrm{K}_{\mathrm{d}}$ and $\mathrm{K}_{\mathrm{oc}}$, which ranged, respectively, from 1.10 to $0.0119 \mathrm{~L} \mathrm{~kg}^{-1}$ and from 25.7 to $20.9 \mathrm{~L} \mathrm{~kg}^{-1}$ at the respective depths of 0-5 and 90-95 cm. Santos et al. (2018) also reported low $\mathrm{K}_{\mathrm{f}}$ values of hexazinone, ranging from 0.06 to $0.73 \mathrm{mg}^{1-1 / \mathrm{n}} \mathrm{kg}^{-1} \mathrm{~L}^{1 / \mathrm{n}}$ in Brazilian soils. The values obtained in the $q_{\max }$ were $<0.28 \mathrm{~g} \mathrm{~kg}^{-1}(0-10 \mathrm{~cm}$ soil depth) (Table 2) and represent the maximum capacity of hexazinone sorption in the different soil profiles.

The coefficients of sorption normalized according to the $\mathrm{OC}$ content $\left(\mathrm{K}_{\mathrm{loc}}\right.$ and $\mathrm{K}_{\mathrm{foc}}$ ) for hexazinone also decreased proportionally with the increase in depth, varying between 28.57 and $19.51 \mathrm{~L} \mathrm{~kg}^{-1}$ for $\mathrm{Kl}_{\mathrm{oc}}$ and between 25.71 and $19.51 \mathrm{mg}^{1-1 / \mathrm{n}} \mathrm{kg}^{-1} \mathrm{~L}^{1 / \mathrm{n}}$ for $\mathrm{K}_{\mathrm{foc}}$. According to PereiraJunior et al. (2015), in a study using contrasting tropical soils of sugarcane crops, at a depth of 0-20 cm, hexazinone had greater retention $\left(\mathrm{K}_{\mathrm{f}}=0.8 \mathrm{mg}^{1-\mathrm{N}} \mathrm{L}^{\mathrm{N}} \mathrm{kg}^{-1}\right)$ in soils with higher OC and clay contents when compared with sandy soils $\left(\mathrm{K}_{\mathrm{f}}=0.2 \mathrm{mg}^{1-\mathrm{N}} \mathrm{L}^{\mathrm{N}} \mathrm{kg}^{-1}\right)$. Mendes et al. (2019) reported that the addition of bovine bone coal to the soil increased the OC content and, consequently, the sorption of hexazinone. Therefore, the results of this study reinforce the importance of soil OC in the sorption of hexazinone, as already evidenced by Oliveira Jr. et al. (2001), Pang et al. (2005), and Sousa et al. (2018).

The sorption isotherms of Freundlich, Linear, and Langmuir for hexazinone at different soil depths are shown in Figure 1. Values of $1 / \mathrm{n}$ near 1 in the sorption of hexazinone indicate that the process was not, in its greatest potential, reversible to the solution of the soil (Table 2).

According to the parameters obtained for the sorption isotherms, the rate of reduction in the amount of the product increased by approximately $4.12 \%$ from the superficial layer at $0-10 \mathrm{~cm}$ to the deepest layer at $20-30 \mathrm{~cm}$, confirming that deeper layers of the soil tend to retain less hexazinone. The percentages of hexazinone sorbed at depths of $0-10,10-20$, and $20-30 \mathrm{~cm}$ were $50.49 \%, 47.58 \%$, and $46.37 \%$, respectively (Table 2). These results indicate that hexazinone is weakly sorbed by the soil, because this herbicide is a weak base and will be poorly laden in the soil, and it seems that hexazinone is sorbed in the soil mainly by means of non-polar mechanisms (Bouchard and Lavy, 1985).

Determination of the leaching rate of hexazinone in the first $30 \mathrm{~cm}$ of the profile of Tropical soils (Mendes et al., 2016; Reis et al., 2017) is important for understanding the sorption process in this soil layer, as reported in this study and, consequently, for evaluating the bioavailability of the product in the soil solution for better efficacy of chemical control of weeds in arable areas. 

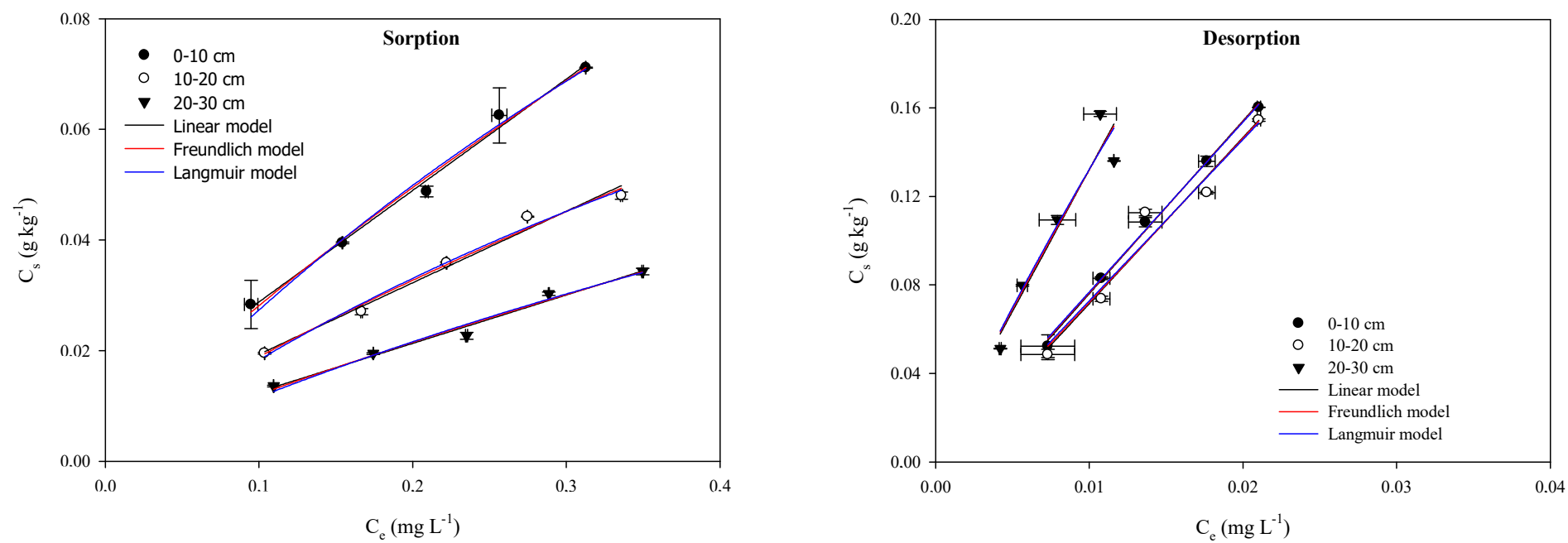

The vertical and horizontal bars represent the standard deviation of the mean $(n=2)$ of the $\mathrm{C}_{\mathrm{e}}$ (concentration of equilibrium herbicide in the soil solution) and $\mathrm{C}_{\mathrm{s}}$ (concentration of sorbed herbicide in the soil), respectively. The symbols can cover the bars.

Figure 1 - Sorption and desorption isotherms of the Linear (black), Freundlich (red) and Langmuir (blue) model for hexazinone applied at different soil depths.

\section{Hexazinone desorption and soil depth}

The values of the desorption coefficients at all soil depths ranged from 7.96 to $9.82 \mathrm{mg}^{(1-1 / \mathrm{n})} \mathrm{L}^{1 / \mathrm{n}} \mathrm{kg}^{-1}$ for $\mathrm{K}_{\mathrm{f}} ; 7.81$ to $12.82 \mathrm{~L} \mathrm{~kg}^{-1}$ for $\mathrm{K}_{\mathrm{d}}$; and from 12.05 to $0.08 \mathrm{~L} \mathrm{~kg}^{-1}$ for $\mathrm{K}_{1}$ (Table 3). Similarly to the non-normalized desorption coefficients, the $\mathrm{K}_{\mathrm{foc}}$ values were 1137.14 to $2395.12 \mathrm{mg}^{(1-1 / \mathrm{n})} \mathrm{L}^{1 / \mathrm{n}} \mathrm{kg}^{-1}$, and $\mathrm{K}_{\mathrm{oc}}$ from 1115.71 to $3126.90 \mathrm{~L} \mathrm{~kg}^{-1}$, increasing with soil depth. The values of $1 / \mathrm{n}$ in the desorption of hexazinone were also $\sim 1$, indicating that the process did not occur to its greatest potential extent (Table 3). These results corroborate those of Pereira-Junior et al. (2015), who found desorption values for hexazinone ranging from $59 \%$ to $89 \%$ of the product that was sorbed in the soil particles, in agreement with the low hysteresis values found by the same authors of 2.1 to 1.6, directly proportional to the OC content of the soil. A study conducted by Bouchard and Lavy (1985) showed desorption of $82.3 \%-89.5 \%$ of hexazinone initially sorbed in the particles of a sandy soil with OC levels varying between $0.63 \%$ and $7.31 \%$, corroborating data from this study suggesting that soils with lower OC levels tend to retain less hexazinone.

Freundlich, Linear, and Langmuir desorption isotherms for hexazinone at different soil depths are shown in Figure 1, and are type C, as in the sorption isotherm (Giles et al., 1974). The type C isotherm describes the relationship between $\mathrm{C}_{\mathrm{e}}$ and $\mathrm{C}_{\mathrm{s}}$ as constant at any concentration. The use of this type of isotherm is restricted to very small initial concentrations, when one is sure that the solute will not occupy all the sorption sites of the surface (Limousin et al., 2007).

The values of the hysteresis coefficients $(\mathrm{H})$ of hexazinone at depths of $0-10,10-20$, and 20-30 cm were low and close to 1, meaning that the desorption process is, in general, reversible, that is, no hysteresis occurs (Table 3). Hysteresis occurs due to the heterogeneity of the sorption sites of the soil colloid surfaces and, consequently, to the various sorption mechanisms between

Table 3 - Parameters of the desorption isotherms of the Linear, Freundlich and Langmuir model and hysteresis coefficient (H) for hexazinone applied at different soil depths

\begin{tabular}{|c|c|c|c|c|c|c|c|c|c|c|c|c|c|}
\hline \multirow{3}{*}{$\begin{array}{l}\text { Soil depth } \\
\text { (cm) }\end{array}$} & \multicolumn{3}{|c|}{ Linear $^{(1)}$} & \multicolumn{5}{|c|}{ Freundlich } & \multicolumn{4}{|c|}{ Langmuir } & \multirow{3}{*}{$\begin{array}{c}\text { Desorption } \\
(\%)\end{array}$} \\
\hline & $\mathrm{K}_{\mathrm{d}}$ & $\mathrm{K}_{\mathrm{oc}}$ & \multirow{2}{*}{$\mathrm{R}^{2}$} & $\mathrm{~K}_{\mathrm{f}}$ & $\mathrm{K}_{\text {foc }}$ & \multirow{2}{*}{$1 / \mathrm{n}$} & \multirow{2}{*}{$\mathrm{R}^{2}$} & \multirow{2}{*}{$\mathrm{H}$} & $\mathrm{K}_{1}$ & $\mathrm{~K}_{\mathrm{loc}}$ & $q_{\max }$ & 2 & \\
\hline & \multicolumn{2}{|c|}{$\left(\mathrm{L} \mathrm{kg}^{-1}\right)$} & & \multicolumn{2}{|c|}{$\left(\mathrm{g}^{1-1 / \mathrm{n})} \mathrm{L}^{1 / \mathrm{n}} \mathrm{kg}^{-1}\right)$} & & & & \multicolumn{2}{|c|}{$\left(\mathrm{L} \mathrm{kg}^{-1}\right)$} & $\left(\mathrm{g} \mathrm{kg}^{-1}\right)$ & & \\
\hline $0-10$ & $7.81 \pm 0.32$ & 1115.71 & 0.99 & $7.96 \pm 0.45$ & 1137.14 & $1.01 \pm 0.03$ & 0.99 & 1.25 & $12.05 \pm 0.82$ & 1721.42 & $92.74 \pm 1.23$ & 0.99 & 26.17 \\
\hline $10-20$ & $7.50 \pm 0.41$ & 1630.43 & 0.98 & $7.93 \pm 0.38$ & 1723.91 & $1.02 \pm 0.04$ & 0.98 & 1.29 & $10.32 \pm 0.75$ & 2243.50 & $87.30 \pm 1.86$ & 0.98 & 26.58 \\
\hline $20-30$ & $12.82 \pm 1.26$ & 3126.90 & 0.96 & $9.82 \pm 0.64$ & 2395.12 & $0.93 \pm 0.06$ & 0.96 & 1.12 & $0.08 \pm 0.01$ & 19.51 & $1.24 \pm 0.13$ & 0.96 & 28.68 \\
\hline
\end{tabular}

(1) Mean value of each parameter, \pm standard deviation of the mean $(n=2)$. 
the herbicide and the soil. Even in the first phase of sorption, many sites exhibit the characteristic of irreversibility, that is, the molecule is strongly retained in soil colloids, which prevents the desorption process from occurring (Celis and Koskinen, 1999).

The percentages of hexazinone remaining in the soil varied with increasing depth, being $26.17 \%, 26.58 \%$, and $28.68 \%$ at depths of $0-10,10-20$, and $20-30 \mathrm{~cm}$, respectively (Table 3 ). This demonstrates that more than half of the initially sorbed product returned to the soil solution, again becoming bioavailable for weed control.

The depths of the soil profile interfered in the process of sorption and desorption of hexazinone, because, as the soil depth increased, there was a decrease in the amount of the herbicide and a small increase in the amount desorbed. These results indicate that small differences in OC content between soil depths affect the retention and transport of hexazinone, interfering in the bioavailability of this product in the soil solution for weed control under field conditions. Further research is needed to evaluate the efficacy of control by this herbicide in the seed bank and/or propagules present in the different layers of the soil profile.

\section{ACKNOWLEDGMENT}

To the National Council for Scientific and Technological Development (CNPq), process 137185/ 2018-9, for the scholarship granted to the first author.

\section{REFERENCES}

Amim RT, Freitas SP, Freitas ILJ, Scarso MF. Banco de sementes do solo após aplicação de herbicidas pré-emergentes durante quatro safras de cana-de-açúcar. Pesq Agropec Bras. 2016; 51:1710-9.

Barriuso E, Laird DA, Koskinen WC, Dowdy RH. Atrazine desorption from smectites. Soil Sci Soc Am J. 1994;58:632-8.

Bonfleur EJ, Kookana RS, Tornisielo VL, Regitano JB. Organomineral interactions and herbicide sorption in Brazilian tropical and subtropical Oxisols under no-tillage. J Agric Food Chem. 2015;64:3925-34.

Bouchard DC, Lavy TL. Hexazinone adsorption-desorption studies with soil and organic adsorbents. J Environ Quality. $1985 ; 14: 181-6$.

Celis R, Koskinen WC. An isotopic exchange method for the characterization of the irreversibility of pesticide sorption-desorption in soil. J Agric Food Chem. 1999;47:782-90.

Cha JS, Park SH, Jung SC, Ryu C, Jeon JK, Shin MC, et al. Production and utilization of biochar: a review. J Ind and Engin Chem. 2016;40: 1-15.

Gaudinski JB, Trumbore SE, Davidson EA, Zheng S. Soil carbon cycling in a temperate forest: radiocarbon-based estimates of residence times, sequestration rates and partitioning of fluxes. Biogeochemestry. 2000;51:33-69.

Giles C, Smith D, Huitson A. A general treatment and classification of the solute adsorption isotherm. I. Theoretical. J Colloid and Interface Sci. 1974;47:755-65.

Green RE, Karickhoff SW. Sorption estimates for modeling. In: SSSA Book Series. Pesticides in the soil environment: processes, impacts and modeling.

Madison WI: 1990. p.79-101.

Koskinen WC, Stone, DM, Harris, AR. Sorption of hexazinone, sulfometuron methyl, and tebuthiuron on acid, low base saturated sands. Chemosphere. 1996;32:1681-9.

Limousin G, Gaudet JP, Charlet L, Szenknect S, Barthes V, Krimissa M. Sorption isotherms: a review on physical bases, modeling and measurement. Appl Geochem. 2007;22:249-75.

Mancuso MAC, Negrisoli E, Perim L. Efeito residual de herbicidas no solo (“carryover”). Rev Bras Herb. 2011;10:151-64. 
Mendes KF, Sousa RN, Takeshita V, Alonso FG, Régo APJ, Tornisielo VL. Cow bone char as a sorbent to increase sorption and decrease mobility of hexazinone, metribuzin, and quinclorac in soil. Geoderma. 2019;343:40-9.

Mendes KF, Inoue MH, Goulart MO, Pimpinato RF, Tornisielo VL. Leaching of a mixture of hexazinone, sulfometuron-methyl, and diuron applied to soils of contrasting textures. Water, Air, \& Soil Pollution. 2016;227:1-9.

Pang L, Close M, Flintoft M. Degradation and sorption of atrazine, hexazinone and procymidone in coastal sand aquifer media. Pest Manage Sci. 2005;61:133-43.

Pereira-Junior EV, Giori FG, Nascimento AL, Tornisielo VL, Regitano JB. Effects of soil attributes and straw accumulation on the sorption of hexazinone and tebuthiuron in tropical soils cultivated with sugarcane. J Environ Sci and Health, Part B. 2015;50:23846.

Oliveira Jr. RS, Koskinen WC, Ferreira FA. Sorption and leaching potential of herbicides on Brazilian soils. Weed Research. 2001;41:97-110.

Organisation for Economic Co-Operation and Development - OECD. Adsorption - desorption using a batch equilibrium method. Paris: 2000. 44p. (OECD, 106).

Pesticide Properties Database - PPDB. Footprint: creating tools for pesticide risk assessment and management in Europe. Developed by the Agriculture \& Environment Research Unit (AERU), University of Hertfordshire, funded by UK national sources and the EU-funded FOOTPRINT project (FP6-SSP-022704). [acesso em: 26 mar 2019]. Disponível em: https:// sitem.herts.ac.uk/aeru/ppdb/en/Reports/384.htm.

Reis FC, Tornisielo VL, Pimpinato RF, Martins BAB, Victória Filho R. Leaching of diuron, hexazinone, and sulfometuron-methyl applied alone and in mixture in soils with contrasting textures. J Agric and Food Chemistry. 2017;65:2645-50.

Rodrigues BN, Almeida FS. Guia de herbicidas. 7ª.ed. Londrina: Editora dos Autores; 2018. 764p.

Santos LOG, Souza MF, Chagas PSF, Fernandes BCC, Silva TS, Dombroski JLD, et al. Effect of liming on hexazinone sorption and desorption behavior in various soils. Arch Agron and Soil Sci. 2018;1:1-13.

Sousa GV, Pereira GAM, Teixeira MFF, Faria AT, Paiva MCG, Silva AA. Sorption and desorption of diuron, hexazinone and mix (diuron + hexazinone) in soils with different attributes. Planta Daninha. 2018;36:1-18.

Taylor JP, Mills MS, Burns RG Sorption and desorption behavior of acetochlor in surface, subsurface and size-fractionated soil. Eur J Soil Sci. 2004;55:671-9.

Wynn JG, Bird MI, Wong VNL. Rayleigh distillation and the depth profile of ${ }^{13} \mathrm{C} /{ }^{12} \mathrm{C}$ ratios of soil organic carbon from soils of disparate texture in Iron Range National Park, Far North Queensland, Australia. Geoch et Cosmoch Acta. 2005;69:1961-73. 